sciendo Порівняльна професійна педагогіка 8(4)/2018 Comparative Professional Pedagogy 8(4)/2018

DOI: $10.2478 /$ rpp-2018-0047

$\mathrm{PhD}$ in Pedagogy, Associate Professor, TETIANA HOROKHIVSKA

Lviv Polytechnic National University, Ukraine

Address: 12 Bandera St., Lviv, 79000, Ukraine

E-mail: t.gorohivska@gmail.com

\title{
DEVELOPING PROFESSIONAL PEDAGOGICAL COMPETENCY OF LECTURERS IN THE LEADING EU COUNTRIES
}

\begin{abstract}
The article deals with the trends in developing professional pedagogical competency of lecturers in the scientific and educational space of the leading EU countries. Specific attention is paid to the analysis of the approaches to determining core competencies required for professional growth, as well as components and criteria for developing professional pedagogical competency in the education systems of the UK, Germany, France, Austria, the Netherlands, Dennmark, Finland. It is highlighted that despite the availability of relevant documents in an integrated Europe, which contain the conceptual framework for acquiring core (basic) competencies, the terms and their criteria differ in each country. It is indicated that in the European Union there is no single approach to understanding the essence, ways and methods for shaping and developing professional pedagogical competency. It is specified that professional pedagogical competency occupies the most important place among the main competencies of lecturers since it is directly related to the performance of professioal duties. It is clarified that when defining the essence of professional pedagogical competency the EU experts pay considerable attention to such qualities of lecturers as the ability to independently solve complex tasks, acquire new knowledge and skills, have a positive view of one's own personality, fruitfully communicate with students and colleagues. It is concluded that the current research made it possible to prove a clear orientation of these countries' state policy towards developing the potential of lecturers, the availability of legal foundations required to ensure support and integrity of lecturers' professional development, a high level of organization and methodical support of the programmes for lecturers' professional development, which are characterized by clear goals and expected outcomes.

Keywords: competency-based approach, professional pedagogical competency, professional development, core competencies, lecturer, teacher education, professional teacher training, the European Union.

\section{INTRODUCTION}

The modern stage of Ukraine's higher education development and its integration into the European and global higher education areas require that the potential of a modern lecturer should be qualitatively enhanced. Under the modern conditions, the lecturer is viewed as a specialist who is knowledgeable of innovative strategies for learning and teaching, is able to involve students in creative activities based on global standards, strives for continuing professional development and is motivated to develop professional pedagogical competency. The study and consideration of international experience in enhancing professional pedagogical competency are the ways to successfully improve professionalism of academic staff.
\end{abstract}




\section{THE AIM OF THE STUDY}

The study aims to analyze the trends in developing professional pedagogical competency of lecturers in the scientific and educational space of the leading EU countries.

\section{THEORETICAL FRAMEWORK AND RESEARCH METHODS}

Some international experience in professional training of lecturers and improvement of professional pedagogical competency were studied by such Ukrainian scholars as N. Avsheniuk, L. Diachenko, O. Ohiienko, O. Ovcharuk, L. Puhovska et al. (Avsheniuk et al., 2014; Avsheniuk et al., 2017; Ovcharuk, 2003). In particular, the problem of teacher training in the UK was investigated by O. Chorna, D. Medvedovska, N. Yatsyshyn et al. (Medvedovska, 2016; Yatsyshyn, 1998). The system of teacher training in France was addressed by V. Lashchykhina (2009), T. Levchenko, N. Postryhach et al. (Avsheniuk et al., 2014; Avsheniuk et al., 2017). The organization of higher teacher education in Germany was examined by B. Bazova (2011), I. Boichevska, L. Diachenko, V. Hladush (2012) et al. (Avsheniuk et al., 2014). Scandinavian education systems were studied by N. Andriichuk, T. Hrabovska, A. Roliak (2010) et al. The Finnish system of teacher education was justified by N. Baseliuk (2013), K. Kovtun et al. (Avsheniuk et al., 2017). The trends in the Belgian system of teacher education were considered by T. Kuchai, Yu. Zakaulova (2008) et al. Different aspects in professional training of lecturers were revealed by J. Buitink (1992), K. Collins, E. Hoton, W. Hutmacher (2008), E. Karweti (2014), M. S. Knowles (Knowles, Hoton, \& Swanson, 1998), M. Mulderns (Mulderns, Weigel, \& Collins, 2007), S. N. Oja (2009), A. Richard et al.

The research methodology included descriptive methods (study, analysis and description of documents, scientific and educational sources) and comparative method (identification of common and distinct pedagogical patterns).

\section{RESULTS}

Innovative achievements of the countries with high-level professional training and development of lecturers in accordance with global standards are of academic interest since they have rich historical traditions of education, considerable experience in training of educators under the new sociocultural conditions (Avsheniuk et al., 2017, p. 5). The education systems of the UK, Germany, France, Austria, the Netherlands, Denmark and Finland are characterized by significant achievements in the quality of professional training for lecturers. Indeed, they have a "scientifically justified, practically verified and thoroughly elaborated complex of teaching skills and competencies of educators" (Avsheniuk et al., 2017, p. 77).

In Europe, the development of teacher education is determined by the main trends characterized by the processes of internationalization, professionalization and modernization of education and targeted at competency-based approach (Bibik et al., 2004). Despite the availability of relevant documents, which contain the conceptual framework for acquiring core (basic) competencies (the European Commission's White Paper on Education and Training (1995), a Memorandum on Lifelong Learning (2000), the eEurope Action Plan (2002), Commission's Action Plan for Skills and Mobility (2002), Standards and Guidelines for Quality Assurance in the European Higher Education Area (2015), etc.) and are recommended for implementation in the education systems of the EU member states, the terms and their criteria differ in each country. Therefore, there is no single approach to understanding the essence, ways and methods for shaping and developing professional pedagogical competency in the European Union. 
The lack of coherence and unanimity is proved by a multi-meaning interpretation of professional competency as "in-depth knowledge", "the ability to perform relevant tasks", "the ability to apply knowledge and skills", "the adequate performance of tasks", etc. (Harhai, 2004). It should be noted that when defining the essence of professional pedagogical competency the EU experts pay considerable attention to such qualities of lecturers as the ability to independently solve complex tasks, acquire new knowledge and skills, have a positive view of one's own personality, fruitfully communicate with students and colleagues (Eurydice, 2002).

E. Karweti (2014) states that professional pedagogical competency occupies the most important place among the main competencies of lecturers since it is directly related to the performance of professioal duties. M. S. Knowles indicates that higher education must cultivate the lecturers who consider lifelong learning and application of knowledge in changing conditions as the most important abilities (Knowles, Hoton, \& Swanson, 1998).

Some scholars emphasize the importance of implementing professional pedagogical competency in the education systems of the EU countries through the use of competencybased approach (Mulder, Weigel, \& Collins, 2007, p. 67). They substantiate the interest in this problem with a number of specific issues related to social and educational trends, including the complexity in defining education principles and insufficient assessment of education organization based on competences, some problems in assessing the level of specialist competency due to improper approaches to its definition.

The UK experience in developing professional pedagogical competency is rather focused on the characteristics of pedagogical activity than personal qualities of lecturers (Oja, 2009). In this regard, it was crucial to determine the most important goals of pedagogical activity, which should be achieved to meet educational requirements of professional competency. Taking into account the fact that pedagogical activity is regulated by professional standards, the Higher Education Academy and British universities have approved the UK Professional Standards Framework for Teaching and Supporting Learning in Higher Education (2011). It encompassess three dimensions in qualitative development of professional pedagogical competency in a modern lecturer: area of expertise, general knowledge, professional values with corresponding descriptors. These descriptors of professional values include the following: respect for every student; assistance to the student in obtaining higher education; use of factual data obtained from research findings on teaching and continuing professional development; understanding of the higher education context, application of professional practice (Medvedovska, 2016).

German scholars consider academic, methodological, social and axiological competencies to be the components of core competencies (Ovcharuk, 2003, p. 19). However, the development of professional pedagogical competency is ensured by a system of postgraduate teacher education, which is rather multilevel and multidivisional and involves two areas. The first area that is advanced teacher training (Lehrerforbildung) is aimed at emhancing professional competency of lecturers so that they can introduce innovations to the education process, apply modern educational methods, enrich knowledge and practical skills in pedagogy, teaching methodology, psychology, etc. The second area that is additional teacher training (Lehrerweiterbildung) implies obtaining a new qualificayion or expanding current professional one (Hladush, 2012). This process is based on the principles of modularity, rational organization of the education process, interdisciplinarity and reflectivity. 
sciendo Порівняльна професійна педагогіка 8(4)/2018 Comparative Professional Pedagogy 8(4)/2018

In contrast to German researchers, Austrian experts in education substantiate the following core competencies: subject-specific competency (mastering and application of knowledge, critical reflection); personal competency (development of individual skills, selfanalysis); social competency (responsibility, activity); communicative competency (communication skills); methodological competency (autonomy, flexibility, purposefulness in learning) (Swiss Federal Statistical Office, 2001, p. 72). It is in the context of developing these competencies that Austrian experts can observe the enhancement of professional pedagogical competency. However, the following aspects of Austrian experience in teacher training are considered to be the most innovative ones: diversification (multidisciplinary) and hybridization of teacher education, the country's clusterization in reforming teacher education, tutoring (Avsheniuk et al., 2014, p. 11).

The development and implementation of national qualification standards based on common requirements for professional training and professional development of teaching staff is characteristic of teacher education in France. Diplomas with qualifications are awarded to the candidates who acquired certain knowledge within the defined standards for professional pedagogical competency. Rather interesting is a modern model for professional training and development of teaching staff in France. The main essential characteristic of such a model is a concentrated approach to developing professional pedagogical competency of lecturers through the use of communication (dialogue-based) exercises, analysis of pedagogical situations, discussions, experimental exercises (Lashchykhina, 2009). Projects presentation, demonstration of educational films, modeling, problem-based methods, role-playing games, micro-teaching are widely used, too.

A slightly different approach to defining the essence of competencies and competence-oriented education is employed by Belgian scholars. Core competencies developed during the education process are social competencies, a positive attitude to external social environment, independent thinking and performance, motivational competencies, mental mobility, functional competencies (OECD, 2011). Belgian experts associate professional pedagogical competency with such criteria as multifunctionality (achieving specific goals, performing various tasks, solving problems), multidimensionality (interconnected combination of knowledge, views, skills and relations), transparency (the possibility of use in different situations), availability (taking into account different content volumes) (Zakaulova, 2008).

In the Netherlands, professional pedagogical competency of lecturers is closely related to defining the major educational goals, including the development of the lecturer's personality, his/her adjustment to new requirements of the education process. Taking as a basis Dutch theorists and educators' suggestion about how to define core competencies in accordance with the requirements of different stages in the individual's life, the following competencies necessary for achieving professional growth were identified: content competencies (necessary for competitiveness in the national and European labour market); competencies necessary for a career (technological competency, operational skills, etc.); competencies necessary for acquiring new skills (basic, analytical abilities and skills) (Swiss Federal Statistical Office, 2001, pp. 255-260).

This suggestion also affects the list of requirements for professional pedagogical competency of lecturers, namely self-directed study abilities; confidence and ability to choose an area for development; ability to solve problems, apply different options, collaborate with colleagues and discover creative solutions; ability to acquire new skills effectively.

It can be argued that modern theoretical developments urge to search for new models in the development of professional pedagogical competency of lecturers. Scientific 
sciendo Порівняльна професійна педагогіка 8(4)/2018 Comparative Professional Pedagogy 8(4)/2018

researches are aimed at studying the ways to deepen the connection between theory and practice in the process of professional pedagogical growth. The main pedagogical functions related to developing this competency were determined as follows: the deepening of lecturers' professional thinking with an emphasis on pedagogical reflection, self-analysis, a harmonious combination of critical and creative understanding of the principles for effective pedagogical activity (Roliak, 2010). After studying educational problems in Denmark, J. Buitink (1992) substantiated the role of practical knowledge in professional growth of the lecturer, which allow him/her to understand any pedagogical situation and take an informed decision instantly, to apply critical thinking skills based on knowledge and experience.

Finnish experts' views on core competencies significantly differ from those common in most European Union countries. They believe that core competencies should include: cognitive competency (theoretical knowledge, practical skills); ability to apply knowledge and skills under the conditions of social change; social competency (ability to cooperate and prevent conflicts, mutual understanding, social adaptability); personal competencies; creative competencies (innovative activity); communicative and pedagogical competencies; administrative competencies; strategic competencies; ability to act in parallel in different fields of activity. In Finland, the development of professional pedagogical competency is incorporated in university curricula as a component of the higher education standard (Hutmacher, 2008; Virolainen, \& Stenström, 2015). This process mainly involves mastering procedural, motivational, semantic components of pedagogical activity, the logic of academic subjects, ability to operate concepts representing the conceptual framework of pedagogy, ability to transform the foundations of pedagogical theory into methods of cognitive activity, acquisition of self-directed study and professional development skills, business communication.

\section{CONCLUSIONS}

The study of current trends in developing professional pedagogical competency of lecturers in the scientific and educational space of the leading EU countries made it possible to prove a clear orientation of these countries' state policy towards developing the potential of lecturers, the availability of legal foundations required to ensure support and integrity of lecturers' professional development, a high level of organization and methodical support of the programmes for lecturers' professional development, which are characterized by clear goals and expected outcomes. The differences in defining the competencies, which are required for professional growth, help to intensify and deepen the debate on the outlined problem between expert teachers in an integrated Europe.

Prospects for further research should be aimed at studying some experience in developing professional pedagogical competency of lecturers in the USA and Canada.

\section{REFERENCES}

1. Avsheniuk, N. M., Desiatov, T. M., Diachenko, L. M., Postryhach, N. O., Pukhovska, L. P., \& Sulyma, O. V. (2014). Kompetentnisnyi pidkhid do pidhotovky pedahohiv u zarubizhnykh krainakh: teoriia ta praktyka. Kirovohrad: Imeks-LTD.

2. Avsheniuk, N. M., Diachenko, L. M., Kotun, K. V., Marusynets, M. M., Ohiienko, O. I., Sulyma, O. V., \& Postryhach, N. O. (2017). Zarubizhnyi dosvid profesiinoi pidhotovky pedahohiv: analitychni materialy. Kyiv: Tsentr.

3. Bazeliuk, N. (2013). Doslidnytsko-bazovana profesiina pidhotovka maibutnikh vchyteliv v universytetakh Finliandii. Pedahohika i psykholohiia profesiinoi osvity, 1, 229-235. 
sciendo Порівняльна професійна педагогіка 8(4)/2018 Comparative Professional Pedagogy 8(4)/2018

4. Bazova, V. I. (2011). Pidhotovka vchyteliv inozemnykh mov u Nimechchyni v umovakh Bolonskoho protsesu. Vziato z http://er.nau.edu.ua/bitstream/NAU/20375/1/aref.doc.doc.

5. Bibik, N. M., Vashchenko, L. S., Lokshyna, O. I., Ovcharuk, O. V., Parashchenko, L. I., Pometun, O. I. ... Trubacheva, S. E. (2004). Kompetentnisnyi pidkhid u suchasnii osviti: svitovyi dosvid ta ukrainski perspektyvy: biblioteka z osvitnoi polityky. Kyiv: K.I.S

6. Buitink, J. (1992). Research on teacher thinking and implications for teacher training. European Journal of Teacher Education, 16 (3), 195-203.

7. Eurydice. (2002). Key competencies: a developing concept in general compulsory education. Retrieved from http://biblioteka-krk.ibe.edu.pl/opac_css/doc_num.php? explnum id $=503$.

$\overline{8}$. Harhai, V. B. (2004). Povyshenye kvalyfykatsyy uchytelei na Zapade: refleksyvnaia model obuchenyia. Pedahohyka, 2, 72-79.

9. Hladush, V. A. (2012). Osoblyvosti pisliadyplomnoi osvity pedahohiv spetsialnykh navchalno-vykhovnykh zakladiv u rozvynenykh krainakh Yevropy. Aktualni pytannia kolektsiinoi osvity, 3, 46-55.

10. Hutmacher, W. (2008). Que tiene de mas el sistema educativo finlandes? Retrieved from https://socialescepcor.wordpress.com/2008/11/29/walo-hutmacher$\% \mathrm{C} 2 \% \mathrm{BFque}$-tiene-de-mas-el-sistema-educativo-finlandes/.

11. Karweti, E. (2014). Influence managerial ability of principals and factors affecting the motivation work on the performance of special-ed teacher. Journal Educational Research, 11 (2), 21-31.

12. Knowles, M. S., Hoton, E. F., \& Swanson, R. A. (1998). The adult learner: the definitive classic in adult education and human resource development (managing cultural differences) (5th ed.). Houston, TX: Gulf Publishing Company.

13. Lashchykhina, V. P. (2009). Rozvytok systemy pidhotovky pedahohichnykh kadriv u Frantsii (druha polovyna XX - pochatok XXI stolittia). (Dys. kand. ped. nauk). Kyivskyi natsionalnyi linhvistychnyi universytet, Kyiv.

14. Mulderns, M., Weigel, T., \& Collins, K. (2007). The concept of competence in the development of vocational education and training in selected EU member states: a critical analysis. Journal of Vocational Education, 59 (1), 67-88.

15. Medvedovska, D. O. (2016). Osnovni kryterii yakosti vyshchoi osvity: dosvid Velykoi Brytanii. Pedahohichni nauky: teoriia, istoriia, innovatsiini tekhnolohii, 4, 48-55.

16. OECD. (2011). OECD reviews of evaluation and assessment in education: school evaluation in the Flemish community of Belgium. Retrieved from https://www.oecdilibrary.org/education/oecd-reviews-of-evaluation-and-assessment-in-education-belgiumflemish-community-2011 9789264116726-en.

17. Oja, S. N. (2009). Perspectives on teacher professional development. London: Falmer Press.

18. Ovcharuk, O. (2003). Suchasni tendentsii rozvytku zmistu osvity v zarubizhnykh krainakh. Shliakh osvity, 2, 17-21. Sysyn O.V

9. Roliak, A. O. (2010). Pidhotovka vchytelia v Danii. Kamianets-Podilskyi:

20. Swiss Federal Statistical Office. (2001). Country Contribution Process: Summary and Country Reports. Briefing materials prepared for DeSeCo's 2nd International Symposium. Neuchâtel, Switzerland: Various Authors. (CCP Reports). Retrieved from http://www.statistik.admin.ch/stat_ch/ber15/deseco/deseco_country.htm. 
sciendo Порівняльна професійна педагогіка 8(4)/2018 Comparative Professional Pedagogy 8(4)/2018

21. Virolainen, M., \& Stenström, M.-L. (2015). Recent Finnish VET reforms and innovations: tackling the current challenges. Retrieved from http://nord-vet.dk/indhold/ uploads/report1c fin.pdf.

22. Yatsyshyn, N. P. (1998). Profesiino-pedahohichna pidhotovka vchyteliv $u$ Velykii Brytanii (90-i roky XX stolittia). (Avtoref. dys. kand. ped. nauk). Natsionalnyi pedahohichnyi universytet imeni M. P. Drahomanova, Kyiv.

23. Zakaulova, Yu. V. (2008). Osoblyvosti funktsionuvannia ta rozvytku systemy vyshchoi profesiinoi osvity frankomovnoi spilnoty Belhii. Problemy suchasnoi pedahohichnoi osvity. Seriia: Pedahohika ta psykholohiia, 19 (2), 14-18. 